\title{
Personalien
}

Todesfälle / Décès / Decessi

Esther Guignard (1942), † 8.8.2017,

8008 Zürich

Franco Lang (1946), † 14.8.2017,

Facharzt für Allgemeine Innere Medizin, 8610 Uster

Harry Trost (1946), † 21.8.2017,

Facharzt für Physikalische Medizin und Rehabilitation und Facharzt für Rheumatologie, 8047 Zürich

Ursula Steiner-König (1939), † 29.8.2017,

Fachärztin für Psychiatrie und Psycho-

therapie, 4052 Basel

Dieter Dürr (1934), † 1.9.2017,

Facharzt für Kinder- und Jugendmedizin, 8810 Horgen

Hugo Obwegeser (1920), † 2.9.2017,

8603 Schwerzenbach

Heinz Klauser (1945), † 2.9.2017,

Facharzt für Allgemeine Innere Medizin, 6982 Agno
Praxiseröffnung /

Nouveaux cabinets médicaux /

Nuovi studi medici

VD

Stéphane Frédéric Wolff, Médecin praticien, Grand-Chêne 8,1003 Lausanne

Ärztegesellschaft des Kantons Luzern

Zur Aufnahme in unsere Gesellschaft Sektion Stadt hat sich gemeldet:

Felix Moltzahn, Facharzt für Urologie, Urologie St. Anna, Ärztehaus Lützelmatt (Trakt L), St. Anna-Strasse 32, 6006 Luzern

Einsprachen sind innert 20 Tagen nach der Publikation schriftlich und begründet zu richten an: Ärztegesellschaft des Kantons Luzern, Schwanenplatz 7, 6004 Luzern

\section{Unterwaldner Ärztegesellschaft}

Zur Aufnahme in die Unterwaldner Ärztegesellschaft hat sich angemeldet:

Annette Gehrig, Fachärztin für Allgemeine Innere Medizin, FMH, Praxisadresse: Marktstrasse 7, 6060 Sarnen
Einsprachen gegen diese Aufnahme sind mit Begründung innert 20 Tagen an die Präsidentin der Unterwaldner Ärztegesellschaft, Dagmar Becker, Mondmattli 3, 6375 Beckenried, zu richten.

\section{Preise / Prix / Premi}

Swiss Society for Infectious Diseases (SSI) Swiss Academic Foundation for Education in Infectious Diseases (SAFE-ID)

The Swiss Society for Infectious Diseases (SSI) and the Swiss Academic Foundation for Education in Infectious Diseases (SAFE-ID) awarded two prizes, each in the amount of $15000 \mathrm{CHF}$ trough equal contributions by the Societies. The two prizes were awarded for excellent publications in basic and clinical infectious diseases during the joint annual meeting in Basel.

In the category «basic research in infectious diseases" the awardee is Jacques Fellay from the Ecole polytechnique fédérale de Lausanne for the work «Severe viral respiratory infections in children with IFIH1 loss-of-function mutations" published in Proceedings of the National Academy of Sciences (PNAS). In the category "clinical research in infectious diseases» the awardee is Angela Huttner from the University Hospital in Geneva for the work «Safety, immunogenicity, and preliminary clinical efficacy of a vaccine against extraintestinal pathogenic Escherichia coli in women with a history of recurrent urinary tract infection: a randomised, single-blind, placebo-controlled phase $1 \mathrm{~b}$ trial" published in Lancet Infectious Diseases. 